\title{
TINDAK PIDANA TERHADAP KESUSILAAN YANG DILAKUKAN TOKOH MASYARAKAT DARI SUDUT PANDANG KRIMINOLOGI
}

\author{
Hartanto \\ Fakultas Hukum Unversitas Widya Mataram (UWM) Yogyakarta \\ hartanto.yogya@gmail.com
}

\begin{abstract}
Crime continues to develop along with the development of society in all fields: political, economic, social, cultural and technological. Almost every day in the newspaper news, as well as electronic media, there is news about criminal acts against decency committed by various groups. Why it happened and how to overcome it is something that will be examined by the author. Cases of sexual decency against women, generally occur because of the imbalance of power relations in question is between men and women, and can also occur because of the imbalance of someone's "figure" in the community against the victim. Crime in general and in decency seems to develop along with the times, no longer see social status or figure. The role of culture, religion, and finally the law must always be fostered to be an element of handling crime against decency
\end{abstract}

\section{Keywords: kejahatan, kesusilaan, tokoh, kriminologi}

\section{LATAR BELAKANG MASALAH}

Tindak pidana terus berkembang seiring perkembangan masyarakat dalam segala bidang: politik, ekonomi, sosial, budaya, maupun teknologi. Hampir setiap hari di berita surat kabar, maupun media terpampang berita mengenai tindak pidana terhadap kesusilaan.

Tindak pidana kesusilaan bisa terjadi dikalangan apapun, mulai dari pengemis, buruh, guru, dosen/profesor, pegawai negeri sipil, pegawai swasta, polisi, dan penegak hukum lain. Tindak pidana ini sangat rentan terhadap semua kategori orang bahkan dari penjahat hingga pemuka agama ataupun tokoh masyarakat. Ujung-ujungnya dapat mengakibatkan tindak pidana lain, yaitu kehamilan tidak diingan/aborsi, kekerasan dalam rumah tangga (KDRT), dan juga meningkatkan jumlah angka perceraian. 
Data dari catatan tahunan Komisi Nasional Perempuan tahun 2018, yang dipublikasikan pada 6 Maret 2019 menunjukkan:

Tahun 2018 jumlah kasus yang dilaporkan meningkat sebesar 14\%. Jumlah kasus kekerasan terhadap perempuan (KTP) 2019 sebesar 406.178, jumlah ini meningkat dibandingkan dengan tahun sebelumnya sebesar 348.466. Sebagian besar data bersumber dari kasus atau perkara yang ditangani oleh Pengadilan Negeri/Pengadilan Agama. Data ini dihimpun dari 3 sumber yakni; Dari PN/Pengadilan Agama sejumlah 392.610 kasus. dari Lembaga layanan mitra Komnas Perempuan sejumlah 13.568 kasus; dari Unit Pelayanan dan Rujukan (UPR) satu unit yang sengaja dibentuk oleh Komnas Perempuan untuk menerima pengaduan korban yang datang langsung ke Komnas Perempuan sebanyak 415 kasus yang datang langsung, dan 367 kasus melalui telpon dan dari Subkomisi Pemantauan yang mengelola pengaduan melalui surat sebanyak 191 kasus dan 261 melalui surat elektronik.

Berdasarkan data-data yang terkumpul tersebut jenis kekerasan terhadap perempuan yang paling menonjol sama seperti tahun sebelumnya adalah KDRT/RP (ranah personal) yang mencapai angka 71\% (9.637). Ranah pribadi paling banyak dilaporkan dan tidak sedikit diantaranya mengalami kekerasan seksual. Posisi kedua KtP di ranah komunitas/publik dengan persentase $28 \%$ (3.915) dan terakhir adalah KtP di ranah negara dengan persentase $0.1 \%$ (16). Pada ranah KDRT/RP kekerasan yang paling menonjol adalah kekerasan fisik 3.927 kasus (41\%), menempati peringkat pertama disusul kekerasan seksual sebanyak 2.988 kasus (31\%), psikis $1.658(17 \%)$ dan ekonomi 1.064 kasus (11\%). Pada ranah publik dan komunitas kekerasan terhadap perempuan tercatat 3.915 kasus. 64\% kekerasan terhadap perempuan di Ranah Publik atau Komunitas adalah Kekerasan Seksual yaitu Pencabulan (1.136), Perkosaan (762) dan Pelecehan Seksual (394). Sementara itu persetubuhan sebanyak 156 kasus. Pencabulan dan persetubuhan merupakan istilah yang banyak digunakan Kepolisian dan Pengadilan karena dasar hukum pasal-pasal dalam KUHAP untuk menjerat pelaku.

Untuk kekerasan di ranah rumah tangga/ relasi personal, selalu sama seperti tahun-tahun sebelumnya kekerasan terhadap istri (KTI) menempati peringkat pertama 5.114 kasus $(53 \%)$, disusul kekerasan dalam pacaran 2.073 kasus (21\%), kekerasan terhadap anak perempuan 1.417 kasus $(14 \%)$ dan sisanya kekerasan mantan suami, kekerasan mantan pacar, serta kekerasan terhadap pekerja rumah tangga

Kasus inses pada tahun 2018 ini sebanyak 1.017 kasus dimana pelaku adalah ayah kandung sebesar 425 orang. Yang juga meningkat di tahun ini pada kekerasan seksual ranah KDRT/ relasi personal adalah angka marital rape dari yang tahun lalu sebanyak 175 kasus menjadi 192 kasus yang 
dilaporkan. Perhatian dan keberanian melaporkan kasus perkosaan dalam perkawinan menunjukkan kesadaran korban bahwa pemaksaaan hubungan seksual dalam perkawinan adalah perkosaan yang bisa ditindaklanjuti ke proses hukum. ${ }^{1}$

\section{Rumusan Masalah}

A. Mengapa terjadi tindak pidana terhadap kesusilaan yang dilakukan oleh tokoh masyarakat?

B. Bagaimana penanggulangan tindak pidana terhadap kesusilaan, terutama yang dilakukan oleh tokoh masyarakat?

\section{METODE PENELITIAN}

Penelitian ini merupakan penelitian hukum normatif dengan pendekatan konseptual (conceptual approach) yaitu mencari asas-asas, doktrin-doktrin dan sumber hukum. Menurut penulis objek penelitian hukum normatif mendasarkan pada isu dari hukum sebagai sistem norma yang digunakan untuk mengkaji/menilai suatu peristiwa hukum.

\section{PEMBAHASAN}

\section{A. Tindak pidana Terhadap Kesusilaan}

Norma masyarakat merupakan salah satu sumber hukum, dan kita ketahui kesusilaan adalah salah satu norma yang hidup dan berkembang dalam masyarakat Indonesia. Kesusilaan adalah abstrak dan diukur dari hati nurani, sehingga sifatnya otonom masing-masing individu.

Asal atau sumber kaedah kesusilaan adalah dari manusia sendiri, jadi bersifat otonom dan tidak ditujukan kepada sikap lahir tetapi ditujukan kepada sikap batin manusia juga." ${ }^{2}$ Dapat disimpulkan bahwa norma

1https://www.komnasperempuan.go.id/read-news-siaran-pers-catatan-tahunan-catahu-komnasperempuan-2019, diakses 10 September 2019

${ }^{2}$ Mertokusumo, Sudikno., 2010. Mengenal Hukum, Universitas Atmajaya, Yogyakarta, hlm 9-10 
kesusilaan menurut Sudikno menitikberatkan pada masalah pribadi individu ketika melihat suatu perbuatan itu jahat misalnya penipuan, pelecehan atau perkosaan apakah dirinya merasa menyesal, malu, takut atau rasa bersalah.

Istilah tindak pidana merupakan terjemahan dari istilah bahasa Belanda strafbaar feit, dipakai juga istilah lain, yaitu delict yang berasal dari bahasa Latin delictum, dalam bahasa Indonesia dipakai istilah delik ${ }^{3}$

Menurut Moeljatno, kata tindak tidak menunjuk kepada hal yang abstrak seperti perbuatan, tapi hanya menyatakan keadaan konkrit. Dalam hal ini perkataan perbuatan yang menunjuk kepada hal yang abstrak ialah menunjuk kepada dua keadaan konkrit; adanya kejadian yang tertentu dan adanya orang yang berbuat atau menimbulkan kejadiaan itu. Sedangkan kata tindak hanya menyatakan keadaan konkrit yaitu, hanya menunjuk kepada suatu kejadian tertentu saja. ${ }^{4}$

Menurut KUHP, kesusilaan terdapat dalam Pasal 281 yaitu dipersamakan dengan kesopan, yaitu merusak kesopanan dimuka umum ataupun dimuka orang lain. Dalam Pasal 283 tindak pidana terhadap kesusilaan dipersamakan dengan perbuatan cabul. Sedangkan dalam Pasal 284 tindak pidana terhadap kesusilaan dipersamakan dengan zina.

Menurut UU No. 23 Tahun 2004 tentang PKDRT, memberikan informasi kepada anak yang belum cukup umur dan/ melakukan kekerasan kepada perempuan dapat dianggap melakukan tindakan kesusilaan.

Menurut Pasal 1 Undang-undang Nomor 44 tahun 2008 tentang Pornografi aktivitas seksual dalam Eksploitasi yang dimaksud adalah muatan pornografi yang diperlihatkan atau dipertunjukkan dimuka umum yang memuat kecabulan seperti gambar bergerak, gerak tubuh, sketsa,

${ }^{3}$ Sofjan Sastrawidjaja. 1996. Hukum Pidana. Ctk Pertama, CV. Armico, Bandung, hlm 111.

${ }^{4}$ Moeljatno, 1993. Asas-asas Hukum Pidana, Ctk Ketujuh, PT Rineka Cipta, Jakarta, hlm 54-55. 
ilustrasi, foto, tulisan, suara, bunyi dan bentuk pesan lain yang melanggar norma kesusilaan. $^{5}$

Menurut UU No. 19 tahun 2016 tentang Perubahan Atas UndangUndang Nomor 11 Tahun 2008 Tentang Transaksi Informasi dan Transaksi Elektronik, pasal 27 ayat (1) dan (3), menyebarkan/mendistribusikan dokumen/berita bermuatan pencemaran nama baik, penghinaan dianggap memiliki kandungan tindak pidana terhadap kesusilaan.

Ketentuan pidana terhadap kesusilaan itu terdapat di dalam pasal 281, 282, dan 283 KUHP. Ketentuan pidana terhadap kesusilaan didepan umum diatur dalam pasal 281 KUHP, Dalam ilmu hukum pidana, tindak pidana yang diatur dalam pasal 281 angka 1 KUHP yang berbunyi “ dipidana dengan pidana penjara selama-lamanya 2 tahun dan 8 bulan atau dengan pidana denda setinggi-tingginya empat ribu lima ratus rupiah”. Barangsiapa dengan sengaja di depan umum merusak kesusilaan; Barangsiapa dengan sengaja merusak kesusilaan didepan oang lain yang kehadirannya disitu bukanlah atas kemauannya sendiri.

Setelah melalui harapan panjang, akhirya Rancangan Undang-Undang KUHP akan mengtur pula tentang delik kesusilaan, yaitu terkait peluasan pasal zina, pemidanaan hidup bersama sebagai suami istri (kumpul kebo), perkosaan dan perbuatan cabul, persetubuhan anak, akses informasi dan layanan alat kontrasepsi, dan pengaturan aborsi.

\section{B. Tokoh Masyarakat}

Tokoh masyarakat dan tokoh agama merupakan panutan perilaku masyarakat yang sangat signifikan ${ }^{6}$ Menurut penulis, tokoh masyarakat adalah orang yang "dituakan" atau memiliki kepedulian dan/ andil di dalam

\footnotetext{
${ }^{5}$ Undang-Undang nomor 44 tahun 2008 tentang Pornografi, Lembaran negara RI Tahun 2008 Nomor 181 Tambahan Lembaran Negara Nomor 4928

6 Azkha N. 2013. Studi Efektivitas Penerapan Kebijakan Perda Kota Tentang Kawasan Tanpa Rokok (KTR) dalam Upaya Menurunkan Perokok Aktif di Sumatera Barat. Jurnal Kebijakan Kesehatan Indonesia.
} 
suatu lingkungan masyarakat di wilayah tertentu, yang umumnya pendapat maupun perilakunya menjadi "panutan" atau menjadi contoh masyarakat di sekitarnya. Dalam perkembangannya tokoh masyarakat dapat juga diakrenakan seseorang dihormati karena memiliki jabatan atau posisi tertentu yang dianggap "tinggi".

Kasus kesusilaan, misalnya kekerasan seksual terhadap perempuan, umunya terjadi karena ketimpangan relasi kuasa yang dimaksud adalah antara laki-laki dan perempuan, dan dapat pula terjadi karena ketimpangan "ketokohan" seseorang dalam masyarakat terhadap korban. Ketimpangan dapat semakin parah ketika satu pihak (pelaku) memiliki kendali lebih terhadap korban. Kendali ini bisa berupa sumber daya, termasuk pengetahuan, ekonomi dan juga penerimaan masyarakat (status sosial/modalitas sosial). Termasuk pula kendali yang muncul dari bentuk hubungan patron-klien atau feodalisme, seperti antara orang tua-anak, majikan-buruh, guru- murid, tokoh masyarakat-warga dan kelompok bersenjata/aparat- penduduk sipil. ${ }^{7}$

Selain kesusilaan dalam arti sempit yaitu seksual, maka contoh dalam arti luas perilaku yang melanggar kesusilaan adalah korupsi, Korupsi seakan menjadi menu utama dalam setiap pemberitaan media apalagi jika melibatkan tokoh yang berpengaruh dan dikenal luas ${ }^{8}$

\section{Kriminologi}

Pengertian kriminologi secara etimologis, kriminologi berasal dari kata crimen yang berarti tindak pidana dan logos berarti ilmu atau pengetahuan. Jadi kriminologi adalah ilmu/pengetahuan tentang tindak pidana. Istilah kriminologi untuk pertama kalinya digunakan oleh P.

\footnotetext{
${ }^{7}$ La Ode Anhusadara \& Rusnib. 2016, Fenomena Kekerasan Seksual Terhadap Anak, Shautut Tarbiyah, Ed. Ke 35 Th. XXII, November 2016, Kendari, hlm 51

${ }^{8}$ Hadiati E, Irwan Abdullah, Wening Udasmoro, 2013, Konstruksi Media Terhadap Pemberitaan Kasus Perempuan Korupsi, Jurnal Al-Ulum, IAIN Gorontalo, 368
} 
Topinand (1879), ahli antropologi Prancis 9 Secara ilmu pengetahuan, seorang tokoh masyarakat tentu memiliki ilmu pengetahuan yang cukup, lalu mengapa ia melakukan tindak pidana terhadap kesusilaan.

Sutherland, mengatakan kriminologi mencakup proses-proses pembuatan hukum, pelanggaran hukum, dan reaksi atas pelanggaran hukum ${ }^{10}$. KUHP kita telah mengatur tentang tindak pidana terhadap kesusilaan dalam Bab XIV., namun karena penegakkan hukum masih lemah maka tetap saja tindak pidana terjadi, selain didorong oleh rasa malu korban dan superioritas pelaku tindak pidana seperti tokoh masyarakat dalam artikel.

Tujuan mempelajari ilmu kriminologi secara umum adalah untuk mempelajari tindak pidana dari berbagai aspek, sehingga diharapkan dapat memperoleh pemahaman mengenai fenomena tindak pidana dengan lebih baik. Fenomena tindak pidana dalam tindak pidana kesusilaan yang dilakukan oleh tokoh masyarakat ini mengandung dimensi sosial, ekonomi, bahkan politik.

Tindak pidana terhadap kesusilaan yang dilakukan oleh tokoh masyarakat jika diurai dari obyek studi kriminologi:

1. Tindak pidana kesusilaan, merupakan norma ketetapan negara yang diatur dalam hukum pidana dan dikenai sanksi;

2. Pelaku, dalam hal ini adalah tokoh masyarakat yang memiliki strata sosial cukup.

3. Reaksi masyarakat, misal "main hakim sendiri" terhadap pelaku. Ketiganya unsur tersebut diatas saling terkait, suatu perbuatan pelaku, baru dapat dikatakan sebagai kejahatan bila ia mendapat reaksi dari

\footnotetext{
${ }^{9}$ Sutherland. Abdussalam, 2007. Membagi Ruang Lingkup Kriminologi, hlm 4 ${ }^{10}$ ibid
} 
masyarakat. $^{11}$ Reaksi masyarakat yang merasa menolak/ tercemar atas perbuatan tindak pidana kesusilaan meski pelaku adalah tokoh masyarakat

\section{Teori Penyebab Terjadi Kejahatan}

Secara teoritis terdapat beberapa faktor penyebab timbulnya kejahatan (faktor etiologi/ etiologi kriminal) yaitu sebagai berikut:

1. Teori yang menggunakan pendekatan biologis, yaitu untuk menjelaskan sebab atau sumber kejahatan berdasarkan fakta dari ciri-ciri biologis, dalam hal ini bisa mendasarkan hubungan antara kejahatan dengan bentuk wajah, tengkorak, postur badan.

2. Teori yang menggunakan pendekatan psikologis, yaitu menjelaskan sebab atau sumber kejahatan berdasarkan masalah kepribadian dan kejiwaan pelaku yang dapat mendorong seseorang berbuat kejahatan. Umumnya pelaku dengan tingkat intelegensi rendah yang melakukan kejahatan, namun menurut penulis hal ini tidak sepenuhnya benar karena fakta dewasa ini pada kejahatan tertentu justru dilakukan oleh orang dengan intelegensi cukup/ tinggi.

Hal ini sesuai dengan pendapat Syamsu Yusuf, bahwa kejahatan dapat dilakukan oleh siapa saja termasuk mahasiswa. Seorang mahasiswa dikategorikan pada tahap perkembangan yang usianya 18 sampai dengan 25 tahun $^{12}$. Menurut Siswoyo, mahasiswa dapat didefinisikan sebagai individu yang sedang menuntut ilmu di tingkat perguruan tinggi, baik negeri maupun swasta atau lembaga lain yang setingkat dengan perguruan tinggi, dinilai memiliki tingkat intelektualitas yang tinggi, kecerdasan dalam berpikir dan kerencanaan dalam bertindak. ${ }^{13}$

\footnotetext{
${ }^{11}$ Topo Santoso dan Eva Achyani Zulfa, 2004, Kriminologi, PT Grafindo Raja Persada, hlm. 11 ${ }^{12}$ Syamsu Yusuf, 2012, Psikologi Perkembangan Anak dan Remaja, Bandung, Remaja Rosdakarya, hlm. 27

${ }^{13}$ Dwi Siswoyo, 2007, Ilmu Pendidikan, Yogyakarta, UNY Press, hlm. 121
} 
3. Teori yang menggunakan pendekatan sosiologi, yaitu menjelaskan faktor-faktor penyebab dan sumber timbul kejahatan berdasarkan interaksi sosial, proses-proses sosial, struktur sosial dalam masyarakat termasuk unsur-unsur kebudayaan, dalam hal ini termasuk ketokohan dalam masyarakat.

\section{E. Tindak Pidana Terhadap Kesusilaan Yang Dilakukan Oleh Tokoh Masyarakat}

Tindak pidana kesusilaan merupakan salah satu masalah sosial yang sangat meresahkan masyarakat sehingga perlu dicegah dan ditanggulangi.

Karakteristik pelaku kekerasan terhadap perempuan, persentase terbesar dari pelaku berpendidikan SLTA ke atas. Sekitar 42 persen pelaku menamatkan pendidikan SLTA, dan sekitar 15 persen berpendidikan universitas. Hal ini menegaskan bahwa seorang yang berpendidikan tinggi tidak menjamin untuk tidak melakukan tindak kekerasan terhadap perempuan $^{14}$

Menurut Mukhlisin, Pelecehan seksual terjadi ketika pelaku mempunyai kekuasaan yang lebih dari pada korban. Kekuasaan dapat berupa posisi pekerjaan yang lebih tinggi, kekuasaan ekonomi, "kekuasaan" jenis kelamin yang satu terhadap jenis kelamin yang lain, dsb. ${ }^{15}$

Both women and men may have internalized societal norms and values that sexual harassment is a 'fact of life' for workers who have low status because of their sex, age, socio-economic class, ethnic group, caste or religious background. ${ }^{16}$

\footnotetext{
${ }^{14}$ Statistik Gender Tematik, 2017. Mengakhiri Kekerasan Terhadap Perempuan dan Anak di Indonesia, Kerjasama Kementrian Pemberdayaan Perempuan dan Perlindungan Anak dengan BPS, Jakarta, hlm 57

15 http://muklisandespar.blogspot.com/2014/04/makalah-pelecehan-seksual-di-dalam.html, diakses 23 Agustus 2019

${ }^{16}$ Nelien Haspels, Zaitun Mohamed Kasim, Constance Thomas and Deirdre McCann, 2001, Action against Sexual Harassment at Work in Asia and the Pacific, ILO-Bangkok, hlm 145
} 
Survei dilakukan oleh koalisi masyarakat sipil yang terdiri dari Hollaback! Jakarta, perEMPUan, Lentera Sintas Indonesia, Perkumpulan Lintas Feminis Jakarta, dan Change.org Indonesia. Diketahui mayoritas perempuan yang menjadi korban pelecehan seksual menggunakan pakaian tertutup saat kejadian. Survei dilakukan terhadap 62.224 orang dari berbagai latar belakang identitas. Dari analisis data responden tersebut, diketahui waktu kejadian pelecehan seksual juga banyak terjadi di siang hari. Mayoritas korban mengaku mengalami pelecehan secara verbal, seperti komentar atas tubuh.

Contoh pada kurun waktu bulan September 2019, tindak pidana kesusilaan yang dilakukan oleh orang yang dikategorikan tokoh masyarakat adalah sebagai berikut :

1. "Paksa Siswi Aliyah Usia 16 Tahun Berhubungan Intim Hingga Hamil, Guru SD Dipesawaran Ditahan" Ditreskrimum Polda Lampung akhirnya menetapkan $\mathrm{W}$, oknum guru sekolah dasar sebagai tersangka dugaan pencabulan siswi Madrasah Aliyah asal Pesawaran. "Untuk tersangka sudah kami amankan kemarin dan mulai penahanan sejak tadi malam," ungkapnya Direktur Reserse Kriminal Umum Polda Lampung Kombes Pol M Barly Ramandhany, Rabu, 11 September 2019. ${ }^{17}$

2. "Cabuli Siswi Kelas 6 Saat Kemping, Oknum Guru SD di Sleman Diadukan ke Polisi” Oknum guru Sekolah Dasar (SD) di Kabupaten Sleman berinisial S dilaporkan ke polisi. Dari cerita korban kepada orangtua, S tidak hanya melakukan tindakan tidak terpuji pada saat di kegiatan camping saja. S pernah melakukan aksinya di UKS sekolah. Menurutnya saat ini anaknya dan korban lainya masih mengalami trauma. Kasat Reskrim Polres Sleman, AKP Rudy Prabowo mengatakan

17 https://www.tribunnews.com/regional/2019/09/11/paksa-siswi-aliyah-usia-16-tahunberhubungan-intim-hingga-hamil-guru-sd-dipesawaran-ditahan, diakses 11 September 2019 
telah menerima laporan dari para orang tua wali murid. ${ }^{18}$ Rabu 11 September 2019.

3. "Magang Jadi Guru, Mahasiswa Asal Sidoarjo Cabuli Murid SMP, Janji Dinikahi 12 Tahun Lagi" Seorang mahasiswa semester akhir di Sidoarjo akhirnya ditahan polisi. Mahasiswa berinisial LTF itu sebelumnya dilaporkan ke polisi karena menyetubuhi murid SMP di sekolah tempat dia menjadi guru magang. Kanit PPA Polrestabes Surabaya, AKP Ruth Yeni mengatakan pemuda 23 tahun asal Sedati Sidoarjo tersebut, dilaporkan telah melakukan pencabulan terhadap korban yang masih berumur 14 tahun. ${ }^{19}$ Senin 9 September 2019

4. "Kepala Sekolah yang Cabuli Siswanya Tak Lama Lagi Disidangkan" Dan kami tunggu pelimpahan tahap II dari Polda Jatim," ungkapnya, Minggu, (1/9/2019). Perbuatan tak patut itu dilakukan sejak Agustus 2018 hingga April 2019. Berdasarkan catatan Tim Penyidik Renakta Ditreskrimum Polda Jatim, terdapat delapan inisial nama yang terlampir sebagai korban. ${ }^{20}$

5. "Fakta Lengkap Oknum Camat Cabuli Siswi SMK, Ia bahkan Berani Beraksi di Hadapan Siswi Lain" Diberitakan ada oknum camat yang bertugas di Kabupaten Sambas diduga mencabuli NA (17) siswi kelas II SMK di Kabupaten Sambas. "Korban ada surat tugas magang di kantor camat. Kejadiannya di dua TKP. Pertama di Kantor Camat, di ruang Camat. Lalu di rumah dinas yang tidak satu lokasi dengan kantor camat," ungkap Kasat Reskrim Polres Sambas, AKP Prayitno, pada Rabu (15/8/2019). "Waktu kejadian di kantor camat 22 Juli dan terakhir 25 Juli. Dilaporkan tanggal 5 Agustus lalu," imbuh AKP Prayitno.

18 https://www.tribunnews.com/regional/2019/09/11/cabuli-siswi-kelas-6-saat-kemping-oknumguru-sd-di-sleman-diadukan-ke-polisi?page=2, diakses 11 September 2019

19 https://www.tribunnews.com/regional/2019/09/11/magang-jadi-guru-mahasiswa-asalsidoarjo-cabuli-murid-smp-janji-dinikahi-12-tahun-lagi. diakses 11 September 2019

20 https://www.tribunnews.com/regional/2019/09/01/kepala-sekolah-yang-cabuli-siswanya-taklama-lagi-disidangkan?page=2, diakses 1 September 2019 
6. "Kronologi Kasus Baiq Nuril, Bermula dari Percakapan Telepon" mantan guru honorer di SMAN 7 Mataram, Nusa Tenggara Barat (NTB), Baiq Nuril Maknun, menuai perbincangan usai dinyatakan bersalah menyebarkan rekaman bermuatan kesusilaan dan dihukum enam bulan penjara serta denda Rp500 juta dalam putusan kasasi Mahkamah Agung (MA). Baiq Nuril pun merasa diperlakukan tidak adil lantaran dirinya adalah korban kasus perbuatan pelecehan yang dilakukan Kepala Sekolah SMAN 7 Mataram, M. Pelecehan itu disebutnya terjadi lebih dari sekali. ${ }^{21}$ Rabu 14 November 2018.

Pada beberapa contoh kasus diatas, ketokohan atau posisi sosial yang dianggap terhormat dari seseorang tetap memungkinkan tindakan pidana terhadap kesusilaan, bahkan tersirat bahwa posisi yang dianggap "lebih tinggi"/tokoh berpotensi lemahnya pengawasan masyarakat terhadap pelaku, sehingga pelaku leluasa untuk melakukan tindak pidana.

\section{F. Penanggulangan Tindak Pidana Terhadap Kesusilaan Yang Dilakukan Oleh Tokoh Masyarakat}

Masalah kejahatan adalah perilaku sosial yang menyimbang yang dihadapi oleh berbagai daerah bahkan negara di dunia ini. Seberapa kuat unsur penangkal kejahatan, seperti kepolisian, masyarakat, budaya dan agama diyakini penulis berperan dalam menentukan jumlah prevalensi sosial dalam kategori kejahatan. Status sosial yaitu ketokohan seseorang dalam masyarakat tidak dapat menjamin bahwa orang tersebut tidak akan berbuat kejahatan (tindak pidana), karena kejahatan pada persepktif sosial merupakan bagian integral dari masyarakat, sehingga masyarakat dalam proses sosialnya senantiasa memiliki tanggung jawab untuk menangkal terjadinya kejahatan.

21 https://www.cnnindonesia.com/nasional/20181114133306-12-346485/kronologi-kasus-baiqnuril-bermula-dari-percakapan-telepon. Diakses 2 September 2019 
Upaya penanggulangan kejahatan yang dilakukan oleh tokoh masyarakat adalah:

1. Menumbuhkan sikap saling peduli untuk menjaga lingkungannya, tanpa melihat ketokohan seseorang/feodalisme.

2. Peningkatan pendidikan dan kesejahteraan masyarakat untuk dapat mengurangi ketimpangan stigma gender, sosial, budaya, ekonomi, atau apapun dalam kaitannya memperkecil celah ordinat dan sub-ordinat dalam masyarakat.

3. Memperbaiki sistim pengawasan untuk mengurangi kesempatan berbuat jahat.

4. Meningkatkan ketangguhan budaya agar wanita dan/ anak tidak dianggap lebih rendah, pemahaman agama, maupun moral serta profesionalisme bagi para tokoh masyarakat maupun penegak hukum

5. Meningkatkan kesadaran hukum masyarakat dan penegakan hukum

\section{KESIMPULAN}

Kejahatan secara umum maupun dalam kesusilaan mengikuti perkembangan jaman, tidak lagi melihat status sosial ataupun ketokohan, maka pandangan tentang ketokohan di dalam masyarakat seyogianya dilakukan dengan wajar, agar tidak menimbulkan kepercayaan yang berlebihan. Tokoh masyarakat sendiri harus senantiasa menghindari hal-hal yang dianggap salah/tabu oleh masyarakat dengan kesadaran bahwa dia dianggap tauladan dan tolak ukur perilaku warga masyarakat, sehingga memiliki amanah untuk menjaga relasi sosial dalam masyarakat.

\section{SARAN}

Patologi sosial bahkan tindak pidana yang justru dilakukan tokoh masyarakat menunjukkan bahwa mencegah tindak pidana bukanlah sekedar membuat hukum positif dan tanggung jawab penegak hukum semata, tapi harus selalu diamati mengapa tindak pidana itu dapat terjadi (akar masalah) sehingga kedepannya masyarakat disarankan dapat mengantisipasi. 
Peran budaya, agama, dan terakhir hukum harus senantiasa dibina untuk menjadi unsur penanggulangan tindak pidana terhadap kesusilaan, serta memberi kontrol sosial, tidak hanya kepada masyarakat melainkan juga kepada tokoh masyarakat.

\section{DAFTAR PUSTAKA}

Azkha N. 2013. Studi Efektivitas Penerapan Kebijakan Perda Kota Tentang Kawasan Tanpa Rokok (KTR) dalam Upaya Menurunkan Perokok Aktif di Sumatera Barat. Jurnal Kebijakan Kesehatan Indonesia.

Dwi Siswoyo, 2007, Ilmu Pendidikan, Yogyakarta, UNY Press.

Hadiati E, Irwan Abdullah, Wening Udasmoro, 2013, Konstruksi Media Terhadap Pemberitaan Kasus Perempuan Korupsi, Jurnal Al-Ulum, IAIN Gorontalo.

La Ode Anhusadara \& Rusnib. 2016, Fenomena Kekerasan Seksual Terhadap Anak, Shautut Tarbiyah, Ed. Ke 35 Th. XXII, November 2016, Kendari.

Nelien Haspels, Zaitun Mohamed Kasim, Constance Thomas and Deirdre McCann, 2001, Action against Sexual Harassment at Work in Asia and the Pacific, ILO-Bangkok.

Mertokusumo, Sudikno., 2010. Mengenal Hukum, Universitas Atmajaya, Yogyakarta.

Moeljatno, 1993. Asas-asas Hukum Pidana, Ctk Ketujuh, PT Rineka Cipta, Jakarta.

Sofjan Sastrawidjaja. 1996. Hukum Pidana. Ctk Pertama, CV. Armico, Bandung.

Sutherland. Abdussalam, 2007. Membagi Ruang Lingkup Kriminologi. Restu Agung, Jakarta.

Statistik Gender Tematik, 2017. Mengakhiri Kekerasan Terhadap Perempuan dan Anak di Indonesia, Kerjasama Kementrian Pemberdayaan Perempuan dan Perlindungan Anak dengan BPS, Jakarta.

Syamsu Yusuf, 2012, Psikologi Perkembangan Anak dan Remaja, Bandung, Remaja Rosdakarya.

Topo Santoso dan Eva Achyani Zulfa, 2004, Kriminologi, PT Grafindo Raja Persada.

\section{UNDANG-UNDANG}

Undang-Undang No. 1 tahun 1946 Republik Indonesia tentang Peraturan Hukum Pidana (KUHP)

Undang-Undang Nomor 44 tahun 2008 tentang Pornografi.

Undang-Undang Nomor 23 tahun 2004 tentang Penghapusan Kekerasan Dalam Rumah Tangga 
Undang-Undang Nomor 19 tahun 2016 tentang Perubahan Atas UndangUndang Nomor 11 Tahun 2008 Tentang Transaksi Informasi dan Transaksi Elektronik

\section{INTERNET}

http://muklisandespar.blogspot.com/2014/04/makalah-pelecehan-seksual-didalam.html, diakses 23 Agustus 2019

https://www.tribunnews.com/regional/2019/09/01/kepala-sekolah-yangcabuli-siswanya-tak-lama-lagi-disidangkan?page $=2$,diakses 1 September 2019

https://www.cnnindonesia.com/nasional/20181114133306-12346485/kronologi-kasus-baiq-nuril-bermula-dari-percakapantelepon. diakses 2 September 2019

https://www.komnasperempuan.go.id/read-news-siaran-pers-catatantahunan-catahu-komnas-perempuan-2019, diakses 10 September 2019

https://www.tribunnews.com/regional/2019/09/11/paksa-siswi-aliyah-usia16-tahun-berhubungan-intim-hingga-hamil-guru-sd-dipesawaranditahan, diakses 11 September 2019

https://www.tribunnews.com/regional/2019/09/11/cabuli-siswi-kelas-6saat-kemping-oknum-guru-sd-di-sleman-diadukan-kepolisi?page=2, diakses 11 September 2019

https://www.tribunnews.com/regional/2019/09/11/magang-jadi-gurumahasiswa-asal-sidoarjo-cabuli-murid-smp-janji-dinikahi-12-tahunlagi. diakses 11 September 2019 